\title{
SOME CRYSTALLOCHEMICAL AND PETROGRAPHIC CRITERIA FOR DETERMINING SOURCE ROCKS AND SEDIMENTARY PROCESSES. THE EXAMPLE OF NEOGENE DEPOSITS OF THE ALPUJARRAN CORRIDOR (BETIC CORDILLERA, SE SPAIN)
}

\author{
F. NIETO, M. ORTEGA-HUERTAS AND N. VELILLA \\ Dpto. Mineralogia y Petrologia e Instituto Andaluz de Geologia Mediterránea, Facultad de Ciencias, \\ Universidad de Granada, Spain
}

(Received 17 June 1988; revised 10 February 1989)

\begin{abstract}
A BSTRACT : The aim of this study was to determine the influence of the various source areas on the Neogene sediments of the Alpujarran Corridor, to ascertain the type and intensity of the sedimentary processes involved, and to establish some generally applicable criteria. At the bottom of the sections the detrital pebbles are derived from the highest nappes of the Alpujárride Complex, whereas those at the top are from the deepest unit of the Nevado-Filábride Complex (the Veleta nappe); between these the entire range of materials from the lower-Alpujárride Complex and the upper-Navado-Filábride Unit (the Mulhacén nappe) is represented. Comparison of the micas and chlorites in the pebbles with those in the conglomerate matrix reveals the effect of the sedimentary processes on every aspect of the crystallochemistry. The $d_{001}$ of the chlorites and the $b_{0}$ of the micas are scarcely affected and can be used to determine the source area. The crystallinity, the Fe content of the chlorites and the basal spacing and angular difference $(\Delta 2 \theta \mathrm{M}-\mathrm{P})$ of the white micas, on the other hand, are all modified, especially in the clay fraction, according to the degree and nature of the alteration of the sediments, and consequently can be used as a guide to the extent of this process.
\end{abstract}

The aim of this study has been firstly to determine to what extent the various source areas have influenced the character of the Neogene sediments of Alpujarran Corridor, and then, through a comparison of the crystallochemical parameters of the phyllosilicates (micas and chlorites) in the pebbles and boulders and in the silt and clay fraction, to ascertain the type and intensity of the sedimentary processes.

\section{STUDY AREA}

The object of this study is the Neogene infilling of the Alpujarran Corridor, which constitutes part of the eastern Betic Depressions. The Alpujarran Corridor forms a narrow intramontane depression $85 \mathrm{~km}$ long and 2-6 km wide within the Betic Cordillera, to the south of the Sierra Nevada and north of the Sierras Lújar, Contraviesa and Gádor (Sanz de Galdeano et al., 1985, 1986). The mineralogy (Ortega Huertas et al. 1985), stratigraphy (Rodríguez Fernández, 1982) and sedimentology-tectonics of the area (Sanz de Galdeano et al., op. cit.) have been well documented. 
As depicted in Fig. 1-I, the stratigraphic section of the various Neogene materials studied is, from bottom to top:

(1) The Cádiar Sequence, composed of reddish conglomerates, sands and clays of the lower Serravallian, together with micaceous silt, containing fauna from the uppermost Serravallian-lowermost Tortonian.

(2) The Ugijar Marine Sequence, consisting of lower Tortonian gypsum, marls and silts.

(3) The Yátor Sequence, comprising conglomerates with intercalated sands and clays dating from the lower Tortonian to the upper Tortonian-Messinian.

(4) The Ugijar Continental Sequence, lying unconformably upon the units described above or sometimes directly upon the substratum, is made up of brown and greyish conglomerates with mica-schist and quartzite pebbles. Toward the central part of the Alpujarran Corridor this unit is better stratified with alternating episodes of conglomerates, sands and clays, all of which represent the mid-zone of an alluvial delta-fan. By analogy with adjacent areas, such as the Guadix Depression and the eastern Almeria Basin, these materials can be dated to the uppermost Miocene-lowermost Pliocene (Cuevas et al., 1984).

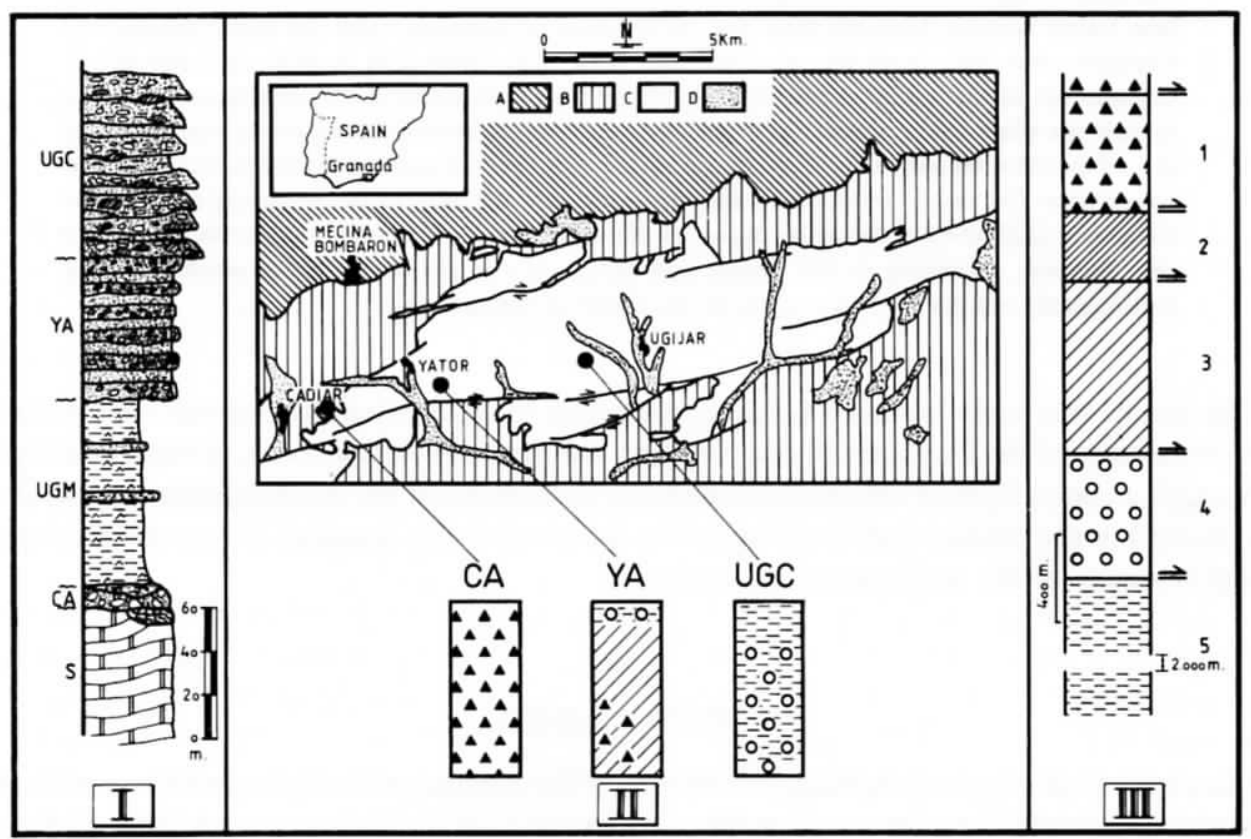

FIG. 1. Stratigraphic sequence (I) and geological map (II) of the Alpujarran Corridor. A: Nevado-Filábride Complex; B: Alpujárride Complex; C: Neogene; D: Alluvial deposits; UGC: Ugijar Continental Sequence; YA: Yátor Sequence; UGM: Ugijar Marine Sequence; CA : Cádiar Sequence; S: Substratum. (Geological Map simplified from Sanz de Galdeano et al., 1985). Tectonic sequence of the source area (III) Alpujárride Complex - 1: Contraviesa Group; 2: Guadalfeo Group; 3: Lújar Group. Nevado-Filábride Complex - 4: Mulhacén Nappe; 5 : Veleta Nappe. 


\section{METHODS}

Representative samples of the different types of pebbles in the conglomerates of the various sequences cropping out in the study area were collected. Thin sections were prepared for petrographic analysis and comparison with the parageneses described by Puga (1971) and Velilla (1983). The 060 spacings of the phengites and chlorites were measured using uncovered sections. Oriented aggregates of the fine fraction were prepared by sedimentation on glass slides to measure the crystallinity and basal spacings of the phengite, paragonite and chlorite, the intensity ratios of the basal reflections of the chlorite, and to determine the type of carbonate present.

All the crystallochemical parameters were obtained with a Philips PW 1710 diffractometer. The basal spacings were measured using the MAX diffractometer program which fixes the reflection maximum by measuring intensities at regular angular intervals for equal periods of time. The experimental conditions were: size of step between points $=0.005^{\circ} 2 \theta$; measuring time at each point $=1 \mathrm{~s}$; number of points on each side of start angle $2 \theta=40$. The quartz content of the sample was used as an internal standard whenever present; if necessary, quartz was added.

The intensity ratios of the 003,004 and 005 reflections of chlorite were measured using a scan speed of $1^{\circ} / \mathrm{min}$, a time constant $=2$, paper speed $=20 \mathrm{~mm} /{ }^{\circ} 2 \theta$, and recorder full scale $=2.10^{3}$ counts. The final figure is the average of five runs.

The crystallinity of the phyllosilicates was determined using the 004 reflection for illite $(5 \AA)$ and paragonite, and the $(003)$ reflection for chlorite using a scan speed of $2^{\circ} / \mathrm{min}$, time constant $=1$, and paper speed $=50 \mathrm{~mm} /{ }^{\circ} 2 \theta$.

The Fe content of the chlorite was calculated from the $b_{0}$ parameter (Brindley, 1961) and/or the intensity ratios of the basal reflections, according to the methods described by Nieto \& Rodriguez Gallego (1983).

The crystallochemical parameters of the phyllosilicates in the silt and clay fractions of the matrix were measured following the same methods which Ortega Huertas et al. (1985) have applied to fine detrital sediments from a similar geological context.

\section{PETROGRAPHY AND CRYSTALLOCHEMICAL PARAMETERS}

\section{Cádiar Sequence}

The predominant rocks in the basal conglomerates are various recrystallized marbles and fine-grained schists. The marbles range from granoblastic to schistose, showing a clear transition between the very pure marbles and the calcitic and/or dolomitic schists. The majority of the schist pebbles in the conglomerates are dark, biotitic mica-schists or quartzmica-schists. Garnet-bearing mica-schists also occur, but to a lesser extent. These pebbles can be attributed petrographically to the Contraviesa Group, the tectonically highest unit of the Alpujárride Complex. The lithology and crystallochemical parameters of the phyllosilicates are shown in Table 1.

\section{Yátor Sequence}

The bottom of the Yátor conglomerate sequence (YA-1) is composed mainly of fine detrital materials; conglomeratic levels containing small carbonate and metapelitic pebbles in roughly equal quantities appear locally. The metapelitic pebbles are on the whole finegrained mica-schists, usually rich in biotite. Chlorite-schists are also to be found, although to 
TABLE 1. Crystallochemical parameters: Cadiar sequence.

\begin{tabular}{rccccccclll}
\hline & \multicolumn{3}{c}{ Phengite } & & \multicolumn{3}{c}{ Paragonite } & \multicolumn{2}{c}{ Chlorite } & \multicolumn{2}{c}{ Crystallinity } \\
Sample & $b_{0}$ & $d_{00,10}$ & $\Delta 2 \theta \mathrm{M}-\mathrm{P}$ & $d_{00,10}$ & $d_{001}$ & $\mathrm{Fe}$ & $\mathrm{Ph}$. & $\mathrm{P}$. & Chl. & Lithology \\
\hline CA-1 & 8.996 & 1.996 & - & - & - & - & 0.19 & - & - & Mica-schist \\
-3 & 8.996 & 1.993 & - & - & - & - & 0.17 & - & - & Biotite-schist \\
-4 & - & 1.993 & 1.72 & 1.924 & - & - & 0.19 & - & - & Mica-schist \\
-5 & - & 1.996 & - & - & - & - & 0.19 & - & - & Biotite-calcite-schist \\
-6 & 8.986 & 1.993 & 1.715 & 1.924 & - & - & 0.19 & 0.20 & - & Calc schist \\
-7 & 8.986 & 1.992 & - & - & 14.15 & 2.38 & 0.18 & - & - & Garnet-schist \\
-8 & 8.990 & 1.991 & - & - & - & - & 0.19 & - & - & Biotite-schist \\
\hline
\end{tabular}

$\Delta 2 \theta$ M-P: angular difference between the 00,10 reflections of muscovite and paragonite.

a lesser extent. The carbonate rocks are marbles containing small quantities of quartz, colourless micas and opaque ores.

In the middle levels of the sequence (YA-2) a transition can be seen in the metapelitic rocks towards a predominance of phyllites over mica-schists within which biotitic schists are scarce. Mica-schist pebbles containing staurolite are also found occasionally. The carbonate rocks are highly recrystallized calcitic marbles.

Towards the top of the sequence the conglomerates are composed of 10-20 cm marble pebbles in a matrix of small fragments of mauvish phyllites. At the very top of the sequence (YA3a and YA3b) the composition of the conglomerates again becomes more heterogeneous. The pebbles in the metapelitic rocks are phyllites, chlorite-schists and various kinds of finegrained mica-schists. The carbonate pebbles are mainly calcitic marbles although they may sometimes be dolomitic and they are variably recrystallized. The lithology and crystallochemical characteristics of the phyllosilicates are shown in Table 2.

The Yátor conglomerate sequence is the most heterogeneous of the three studied as regards its pebbles which are derived almost entirely from the Alpujárride Complex. The pebbles at the bottom of the sequence come mainly from the highest of the tectonically imposed Alpujarride nappes (the Contraviesa Group), while at the top they almost all derive from the lower ones (the Guadalfeo Group), with a lesser contribution from the NevadoFilábride underneath.

\section{Ugijar Continental Sequence}

The two lower levels (UGC-1a and UGC-1b) contain great quantities of decimetre-sized boulders of gneisses, marbles and various kinds of schists, especially garnet-bearing graphitemica-schists, with or without chloritoid, and feldspathic mica-schists. These boulders clearly come from both the Veleta and the Mulhacen nappes of the Nevado-Filábride Complex; no evidence of any Alpujárride influence is to be found.

The top of this sequence (UGC-2) is a conglomerate with a scanty fine matrix containing relatively homogeneous decimetre-sized, often imbricated, boulders. The rocks are garnetbearing mica-schists and quartz-mica-schists, with feldspathic mica-schists and quartzschists in small quantities. These boulders can be attributed petrographically with confidence to the Veleta Group (Ragua Unit) of the Nevado-Filábride Complex, according to criteria established by Puga (1971) and Velilla (1983). Various data on the rocks in this sequence appear in Table 3. 
TABLE 2. Crystallochemical parameters: Yator sequence.

\begin{tabular}{|c|c|c|c|c|c|c|c|c|c|c|}
\hline \multirow[b]{2}{*}{ Sample } & \multicolumn{2}{|c|}{ Phengite } & \multirow[b]{2}{*}{$\Delta 2 \theta \mathrm{M}-\mathrm{P}$} & \multirow{2}{*}{$\begin{array}{c}\text { Paragonite } \\
d_{00,10}\end{array}$} & \multicolumn{2}{|c|}{ Chlorite } & \multicolumn{3}{|c|}{ Crystallinity } & \multirow[b]{2}{*}{ Lithology } \\
\hline & $b_{0}$ & $d_{00,10}$ & & & $d_{001}$ & $\mathrm{Fe}$ & $\mathrm{Ph}$. & P. & Chl. & \\
\hline YA3b-2 & $9 \cdot 014$ & 1.993 & - & - & $14 \cdot 17$ & $1 \cdot 35$ & - & - & - & Gneiss \\
\hline-6 & $9 \cdot 007$ & 1.994 & 1.735 & 1.925 & $14 \cdot 14$ & 1.46 & $0 \cdot 18$ & $0 \cdot 17$ & $0 \cdot 15$ & Sandstone \\
\hline-8 & 8.988 & 1.991 & 1.665 & 1.925 & $14 \cdot 13$ & $2 \cdot 51$ & $0 \cdot 18$ & - & $0 \cdot 20$ & Garnet-schist \\
\hline-9 & 8.982 & 1.992 & - & - & - & - & $0 \cdot 20$ & - & - & Mica-schist \\
\hline-11 & 9.035 & 1.993 & - & - & - & - & $0 \cdot 16$ & - & - & Marble \\
\hline-13 & $9 \cdot 047$ & 1.995 & - & - & - & - & - & - & - & Marble \\
\hline-14 & $9 \cdot 016$ & 1.993 & 1.75 & 1.923 & - & - & $0 \cdot 19$ & - & - & Limestone \\
\hline-15 & $9 \cdot 008$ & 1.995 & - & - & $14 \cdot 17$ & 0.95 & - & - & - & Gneiss \\
\hline-16 & 8.992 & 1.991 & 1.75 & 1.925 & $14 \cdot 14$ & $2 \cdot 41$ & $0 \cdot 18$ & $0 \cdot 19$ & $0 \cdot 18$ & Garnet-chloritoid-schist \\
\hline YA3a-1 & - & 1.994 & 1.795 & 1.923 & $14 \cdot 14$ & $2 \cdot 14$ & $0 \cdot 19$ & - & $0 \cdot 17$ & Chlorite-schist \\
\hline-3 & $9 \cdot 000$ & 1.996 & 1.815 & 1.923 & $14 \cdot 16$ & - & $0 \cdot 17$ & $0 \cdot 17$ & $0 \cdot 19$ & Mica-schist \\
\hline-6 & $9 \cdot 019$ & 1.995 & $1 \cdot 785$ & 1.924 & $14 \cdot 15$ & - & 0.20 & $0 \cdot 21$ & - & Phyllite \\
\hline-7 & - & 1.993 & - & - & - & - & $0 \cdot 20$ & - & - & Marble \\
\hline-8 & $9 \cdot 014$ & 2.014 & - & - & - & - & $0 \cdot 19$ & - & - & Marble \\
\hline-10 & $9 \cdot 011$ & 1.995 & 1.80 & 1.923 & - & - & $0 \cdot 17$ & $0 \cdot 17$ & - & Calcite-mica-schist \\
\hline-11 & - & - & - & - & $14 \cdot 16$ & 1.84 & - & - & $0 \cdot 18$ & Chlorite-schist \\
\hline-12 & 9.019 & 1.995 & - & - & - & - & $0 \cdot 17$ & - & - & Biotite-garnet-schist \\
\hline-13 & - & 1.994 & - & - & - & - & - & - & - & Marble \\
\hline-14 & $9 \cdot 001$ & 1.992 & - & - & $14 \cdot 16$ & - & $0 \cdot 17$ & - & $0 \cdot 17$ & Epidote-plagioclase-schist \\
\hline-16 & $9 \cdot 002$ & 1.997 & - & - & - & - & $0 \cdot 17$ & - & - & Marble \\
\hline-17 & 8.988 & 1.993 & - & - & $14 \cdot 13$ & $2 \cdot 51$ & $0 \cdot 16$ & - & $0 \cdot 18$ & Garnet-chloritoid-schist \\
\hline YA2-2 & $9 \cdot 009$ & 1.994 & - & - & - & - & $0 \cdot 15$ & - & - & Marble \\
\hline-3 & $9 \cdot 008$ & 1.995 & 1.79 & 1.924 & - & - & $0 \cdot 19$ & $0 \cdot 21$ & - & Phyllite \\
\hline-4 & 8.981 & 1.989 & 1.62 & 1.924 & - & - & $0 \cdot 19$ & $0 \cdot 21$ & - & Mica-schist \\
\hline-5 & $9 \cdot 014$ & 1.994 & $1 \cdot 725$ & 1.925 & - & - & $0 \cdot 18$ & - & - & Mica-schist \\
\hline-6 & $9 \cdot 020$ & 1.995 & 1.805 & 1.923 & - & - & $0 \cdot 18$ & $0 \cdot 19$ & - & Phyllite \\
\hline-7 & - & 1.994 & - & - & $14 \cdot 15$ & $3 \cdot 30$ & - & - & - & Staurolite-biotite-schist \\
\hline-9 & $9 \cdot 001$ & 1.995 & - & - & - & - & $0 \cdot 14$ & - & - & Marble \\
\hline-11 & $9 \cdot 016$ & 1.994 & $1 \cdot 78$ & 1.923 & - & - & $0 \cdot 15$ & $0 \cdot 16$ & - & Phyllite \\
\hline-14 & $9 \cdot 010$ & 1.995 & $1 \cdot 745$ & 1.923 & - & - & $0 \cdot 18$ & - & - & Calc schist \\
\hline-15 & $9 \cdot 021$ & 1.993 & 1.745 & 1.923 & $14 \cdot 17$ & $0 \cdot 80$ & $0 \cdot 18$ & $0 \cdot 22$ & $0 \cdot 18$ & Phyllite \\
\hline YA1-1 & 8.989 & 1.996 & - & - & $14 \cdot 14$ & $2 \cdot 51$ & $0 \cdot 18$ & - & $0 \cdot 15$ & Mica-schist \\
\hline-2 & 8.999 & 1.992 & 1.62 & 1.927 & $14 \cdot 15$ & $2 \cdot 32$ & 0.19 & - & $0 \cdot 17$ & Chlorite-schist \\
\hline-3 & 8.986 & 1.992 & - & - & - & - & $0 \cdot 18$ & - & - & Biotite-schist \\
\hline-4 & 8.993 & 1.992 & 1.59 & 1.928 & $14 \cdot 13$ & 3.00 & $0 \cdot 21$ & - & - & Biotite-schist \\
\hline-5 & 8.991 & 1.991 & - & - & - & - & 0.19 & - & - & Chlorite-biotite-schist \\
\hline-6 & 8.980 & - & - & - & - & - & 0.20 & - & - & Biotite-schist \\
\hline-7 & - & 1.990 & 1.535 & 1.928 & $14 \cdot 14$ & $2 \cdot 70$ & $0 \cdot 19$ & $0 \cdot 21$ & $0 \cdot 17$ & Biotite-schist \\
\hline
\end{tabular}

$\Delta 2 \theta$ M-P: angular difference between the 00,10 reflections of muscovite and paragonite.

\section{THE SOURCE AREA FOR THE CONGLOMERATES}

As mentioned above, the pebbles in the Cádiar Sequence all come from the same source area, the uppermost nappes of the Alpujárride Complex (the Contraviesa Group, according to Aldaya et al., 1981), which have the highest thermal gradient of all the rocks in this area. This is supported by both the petrographic evidence, and by the very uniform values of the crystallochemical parameters for the micas which are characteristic of micas formed at high temperatures. These temperatures are the reason for the scarcity or complete absence of 
TABLE 3. Crystallochemical parameters: Continental Ugijar sequence.

\begin{tabular}{|c|c|c|c|c|c|c|c|c|c|c|}
\hline \multirow[b]{2}{*}{ Sample } & \multicolumn{2}{|c|}{ Phengite } & \multirow[b]{2}{*}{$\Delta 2 \theta \mathrm{M}-\mathrm{P}$} & \multirow{2}{*}{$\begin{array}{l}\text { Paragonite } \\
\qquad d_{00.10}\end{array}$} & \multicolumn{2}{|c|}{ Chlorite } & \multicolumn{3}{|c|}{ Crystallinity } & \multirow[b]{2}{*}{ Lithology } \\
\hline & $b_{0}$ & $d_{00,10}$ & & & $d_{00}$ & $\mathrm{Fe}$ & $\mathrm{Ph}$. & P. & Chl. & \\
\hline SC2 -1 & 8.998 & 1.991 & $1 \cdot 705$ & 1.924 & - & - & $0 \cdot 17$ & $0 \cdot 19$ & - & Garnet-schist \\
\hline-2 & 8.994 & 1.994 & 1.74 & 1.925 & - & - & $0 \cdot 19$ & $0 \cdot 19$ & - & Garnet-schist \\
\hline-3 & - & 1.991 & 1.65 & 1.925 & - & - & $0 \cdot 16$ & $0 \cdot 17$ & - & Mica-schist \\
\hline-4 & 8.991 & 1.991 & 1.645 & 1.925 & - & - & $0 \cdot 18$ & - & - & Garnet-schist \\
\hline-5 & 8.988 & 1.994 & 1.715 & 1.925 & - & - & $0 \cdot 17$ & $0 \cdot 20$ & - & Mica-schist \\
\hline-6 & $9 \cdot 001$ & 1.993 & 1.64 & 1.927 & - & - & $0 \cdot 18$ & 0.21 & - & Garnet-schist \\
\hline-7 & 8.995 & 1.994 & - & - & - & - & $0 \cdot 18$ & - & - & Garnet-schist \\
\hline-9 & 8.992 & 1.994 & $1 \cdot 73$ & 1.925 & - & - & $0 \cdot 16$ & 0.21 & - & Garnet-schist \\
\hline-10 & 8.992 & 1.994 & 1.725 & 1.925 & - & - & $0 \cdot 18$ & $0 \cdot 19$ & - & Garnet-schist \\
\hline-11 & 8.989 & 1.992 & 1.67 & 1.925 & - & - & $0 \cdot 17$ & $0 \cdot 18$ & - & Garnet-schist \\
\hline-12 & 8.989 & - & - & - & - & - & $0 \cdot 18$ & - & - & Mica-schist \\
\hline UGC1b-4 & 8.988 & 1.996 & - & - & $14 \cdot 13$ & $2 \cdot 64$ & $0 \cdot 20$ & - & $0 \cdot 18$ & Garnet-schist \\
\hline-5 & 8.990 & 1.994 & - & - & $14 \cdot 14$ & $2 \cdot 51$ & $0 \cdot 17$ & - & $0 \cdot 17$ & Garnet-schist \\
\hline-7 & $9 \cdot 008$ & 1.995 & - & - & $14 \cdot 15$ & 1.65 & $0 \cdot 21$ & - & $0 \cdot 14$ & Garnet-epidote-schist \\
\hline-8 & 8.999 & 1.996 & - & - & $14 \cdot 13$ & $2 \cdot 08$ & $0 \cdot 18$ & - & - & Garnet-plagioclase-schist \\
\hline-9 & 9.010 & 1.995 & - & - & - & - & $0 \cdot 19$ & - & - & Quartzite \\
\hline-18 & 8.997 & 1.995 & - & - & $14 \cdot 13$ & $2 \cdot 55$ & $0 \cdot 17$ & - & - & Garnet-schist \\
\hline-20 & 8.990 & 1.993 & 1.675 & 1.926 & $14 \cdot 14$ & $2 \cdot 89$ & $0 \cdot 17$ & - & $0 \cdot 17$ & Garnet-plagioclase-schist \\
\hline-21 & 8.989 & 1.995 & - & - & $14 \cdot 14$ & $2 \cdot 76$ & $0 \cdot 18$ & - & - & Plagioclase-schist \\
\hline-22 & 8.992 & 1.991 & $1 \cdot 645$ & 1.925 & $14 \cdot 13$ & $2 \cdot 65$ & $0 \cdot 19$ & - & - & Garnet-plagioclase-schist \\
\hline-23 & 8.993 & 1.992 & 1.695 & 1.925 & $14 \cdot 13$ & $2 \cdot 62$ & $0 \cdot 18$ & - & $0 \cdot 20$ & Garnet-plagioclase-schist \\
\hline-25 & 8.992 & 1.996 & 1.775 & 1.925 & $14 \cdot 12$ & $2 \cdot 46$ & $0 \cdot 18$ & - & - & Garnet-chloritoid-schist \\
\hline-26 & 8.991 & 1.993 & 1.71 & 1.924 & $14 \cdot 14$ & $2 \cdot 41$ & $0 \cdot 19$ & - & $0 \cdot 14$ & Garnet-plagioclase-schist \\
\hline-29 & $9 \cdot 002$ & 1.995 & 1.69 & 1.927 & - & - & $0 \cdot 20$ & 0.20 & - & Chloritoid-schist \\
\hline-30 & 8.994 & 1.990 & 1.645 & 1.925 & $14 \cdot 16$ & - & $0 \cdot 17$ & - & - & Staurolite-garnet-schist \\
\hline UGCla-1 & 9.039 & 1.991 & - & - & $14 \cdot 17$ & 1.20 & $0 \cdot 19$ & - & $0 \cdot 15$ & Gneiss \\
\hline-2 & 8.996 & - & - & - & - & $2 \cdot 19$ & - & - & - & Garnet-schist \\
\hline-3 & 8.989 & 1.994 & - & - & $14 \cdot 12$ & $2 \cdot 22$ & $0 \cdot 20$ & - & $0 \cdot 16$ & Garnet-schist \\
\hline-4 & 8.990 & 1.994 & - & - & $14 \cdot 14$ & $2 \cdot 55$ & $0 \cdot 17$ & - & $0 \cdot 20$ & Garnet-schist \\
\hline-5 & $9 \cdot 015$ & 1.993 & - & - & $14 \cdot 16$ & $1 \cdot 50$ & $0 \cdot 17$ & - & $0 \cdot 17$ & Plagioclase-epidote-schist \\
\hline-7 & 8.998 & 1.993 & $1 \cdot 70$ & 1.925 & $14 \cdot 11$ & $2 \cdot 14$ & $0 \cdot 20$ & $0 \cdot 17$ & $0 \cdot 17$ & Chloritoid-schist \\
\hline
\end{tabular}

$\Delta 2 \theta$ M-P: angular difference between the 00,10 reflections of muscovite and paragonite.

chlorite and paragonite, with the result that the only crystallochemical parameters available are the $b_{0}$ and $d_{00,10}$ of the phengites. The values of $\sim 8.99 \AA$ and $1.993 \AA$, respectively are appropriate to both the materials of the most highly metamorphosed nappes of the Alpujárride Complex, and to those of the Nevado-Filábride Complex, especially the Veleta Nappe (Martín Ramos, 1977). Nevertheless, the petrographic evidence confirms their assignation to the Alpujárride Complex.

The pebbles in the Yátor sequence, however, come from a variety of source rocks and marked differences can be seen from outcrop to outcrop. The source area was predominantly Alpujárride, but a certain contribution from the Nevado-Filàbride Complex is evident at the top. The specific contribution made by each unit of the source complexes can be clearly identified within the various levels of this sedimentary sequence. At the bottom (YA-1) the rocks are very similar to those described above for the Cádiar sequence. Some samples contain paragonite, although the degree of paragonitization $(\Delta 2 \theta \mathrm{M}-\mathrm{P}=1.62)$, is 
characteristic of the highest thermal limit for this mineral (Evans \& Guidotti, 1966; Martín Ramos \& Rodríguez Gallego, 1976). The same petrographic criteria as applied to the Cádiar sequence and the degree of paragonitization rule out any possible Nevado-Filábride origin for the pebbles of these levels, and point to an Alpujárride source.

In the middle levels (YA-2), phyllites predominate and thus the crystallochemical parameters for the phyllosilicates show values corresponding to lower temperatures; the most characteristic values, such as the $b_{0}$ of the phengite $(>9.00 \AA)$ and $\Delta 2 \theta \mathrm{M}-\mathrm{P}>1 \cdot 7^{\circ} 2 \theta$, clearly demonstrate their Alpujárride origin (Martín Ramas, 1977; Nieto, 1983). Although the majority of the rocks in this sequence come from the lower Alpujárride nappes (Lújar and Guadalfeo Groups) and/or the less metamorphosed materials of the tectonically-imposed Contraviesa Group, there are more highly metamorphosed pebbles, though not to the same extent as those in the Cádiar sequence.

In the upper levels (YA3a and YA3b), the contribution from the Nevado-Filábride Complex is still small. The Alpujárride Complex is mainly represented by carbonate rocks together with metapelites from less highly metamorphosed materials, and their crystallochemical parameters reveal a range of values similar to those described above for the Alpujárride low-thermal-gradient rocks. The rocks in these two outcrops that are derived from the NevadoFilábride Complex come from both the Mulhacèn and the Veleta Nappes. The extraordinary lithological variety to be found in this former nappe means that the phyllosilicates have very diverse crystallochemical parameters, although they can always be clearly grouped into rock types (marbles, schists or gneisses) and almost always can be differentiated from similar rocks belonging to other units. Thus, in the YA3b outcrop the $b_{0}$ parameter of the phengites distinguishes between the Mulhacén marbles, the $b_{0}$ values of which are $>9.03 \AA$, and the Alpujárride carbonate rocks, with values of $\sim 9.01 \AA$. The pebbles from the Veleta Nappe can similarly be identified by the crystallochemical parameters of their phyllosilicates (Martin Ramos, 1977).

The materials of the Ugijar Continental Sequence bear witness to the continuation of the evolutionary process which started with the higher Alpujárride nappes in the Yátor Sequence. The lower level of this sequence (UGC-1) contains pebbles derived from both the Mulhacén and Veleta Nappes in equal proportions, together with a minor quantity of rocks that, while undoubtedly coming from the Nevado-Filábride, are difficult to assign with greater precision.

It is worth emphasising the difference, already mentioned for the YA-3 outcrop, between the schists derived from the Mulhacén Nappe and those from the Veleta Nappe. The phyllosilicates from the latter show extraordinarily constant crystallochemical parameters with a very narrow range of values (Martín Ramos, 1977). On the other hand, the samples from the Mulhacén Nappe generally have one or several parameters which differ from those above and which allow assignment with confidence to this unit, i.e. the $b_{0}$ of the phengite $>9.00 \AA$, the 00,10 of the phengite $>1.996 \AA$, the $d(001)$ of the chlorite $>14.16 \AA$ and the low Fe content of the chlorite ( $<2.0$ atoms) (Martín Ramos, op.cit.; Nieto, 1983).

The upper levels (UGC-2) are composed entirely of materials from the Veleta Nappe and are lithologically very uniform in character.

The lithological section of the Alpujarran Corridor Neogene (Fig. 1-II) clearly reveals the evolution of the source area. At the base of the series (the Cádiar sequence), the detrital pebbles are derived from the highest nappes of the Alpujárride Complex, while those at the top (the Continental Ugijar sequence) come from the deepest unit of the Nevado-Filábride Complex (the Veleta Nappe), and between these the entire range of materials from the lower 
Alpujárride Complex and the upper Nevado-Filábride Unit (the Mulhacén Nappe) are represented.

\section{CRYSTALLOCHEMICAL PARAMETERS FOR THE ROCKS OF THE SOURCE AREAS}

In Fig. 2 the values of the crystallochemical parameters are represented as histograms of frequency, and grouped according to possible source areas. Only those samples for which there were no crystallochemical nor petrographic problems regarding their assignation have been included. The data compare well with those in the literature (Martín Ramos, 1977; Nieto, 1983), and thus we are reasonably confident in the assignations of the source areas for these sediments. Nevertheless, analysis of the parameters (Fig. 2) leads to some conclusions which are of particular interest.

The crystallochemical parameters on the whole have a smaller range of values for the conglomerates than for the source area (Martín Ramos, op. cit.; Nieto, op. cit.). This is logical bearing in mind that the source rocks for the conglomerates were those geographically most adjacent, and thus did not necessarily represent the entire range of materials making up the whole geological unit. In fact, the crystallochemical parameters for the phyllosilicates of the pebbles derived from the Veleta Nappe, a lithologically fairly monotonous unit, coincide with those reported in the literature for the rocks belonging to this unit (Martin Ramos, 1977).

One point worth emphasising is the almost constant discrepancy $\left(0.05^{\circ} 2 \theta\right)$ between the values for the muscovite-paragonite angular difference ( $\triangle \mathrm{M}-\mathrm{P} 2 \theta)$ and the higher ones described in the literature (Martin Ramos, 1977; Nieto, 1983). This difference is also reflected in the very slightly lower values which Nieto obtained in 1983 compared to those of Martín Ramos in 1977, and a similar tendency found recently by López Aguayo et al. (1986). It may be that this diminution in the values is the result of the improved measuring techniques now available, the graphic register method having been replaced by the automatic localization of maximum intensities by regular interval measurements.

The crystallochemical parameters set out in Fig. 2 show not only the difference between the pebbles from the various source areas but also indicate the several different lithologies within each of these source areas. These differences often hinder the clear assignation of the rocks to any one specific source if the crystallochemical parameters alone are taken into account. In Fig. 2, after an initial tentative attempt, we have only included as different materials those which showed distinct crystallochemical behaviours. Thus, within the Alpujárride Complex, only differences due to the degree of metamorphism appear, and not differences in the lithology of the rocks as this variable has not been taken into account, whereas the opposite applies to the Mulhacén Nappe.

\section{THE EFFECTS OF EXOGENOUS PROCESSES ON THE CRYSTALLO- CHEMICAL PARAMETERS OF THE PHYLLOSILICATES}

In all the conglomerate levels with sufficient matrix, the $<2 \mu \mathrm{m}$ and $2-20 \mu \mathrm{m}$ fractions have been studied in order to determine the same parameters as those established for the pebbles. Some of the data referring to the matrix measurements have been taken from Ortega Huertas et al. (1985). In Fig. 3 the values for the matrix are shown along with the mean values, standard deviations and the range of values for the pebbles in the same level for comparison. 
a

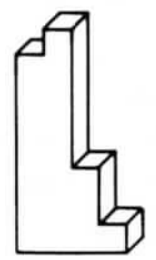

b

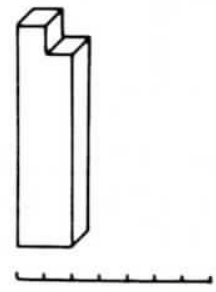

C

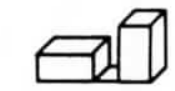

d

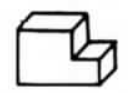

e
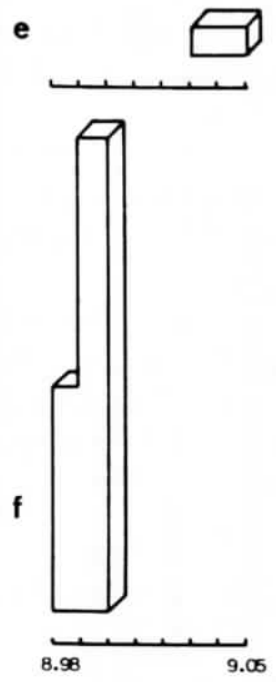

$b_{0}(A)$ Phengite
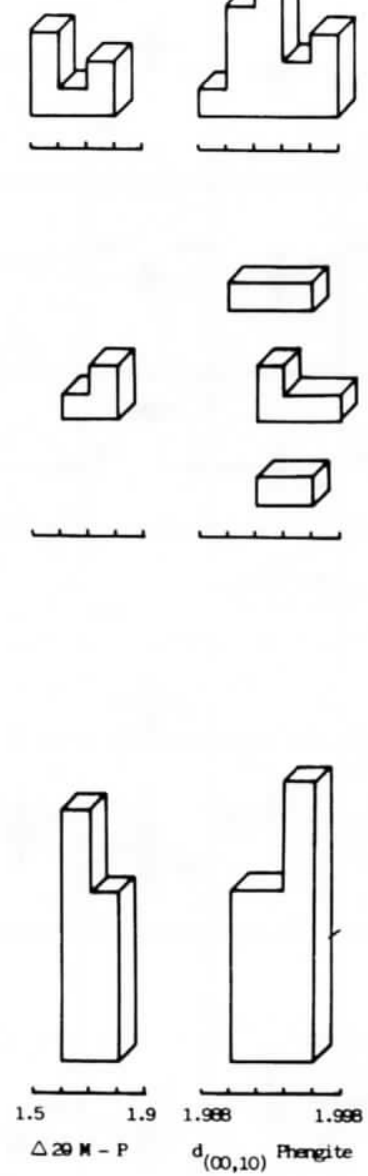
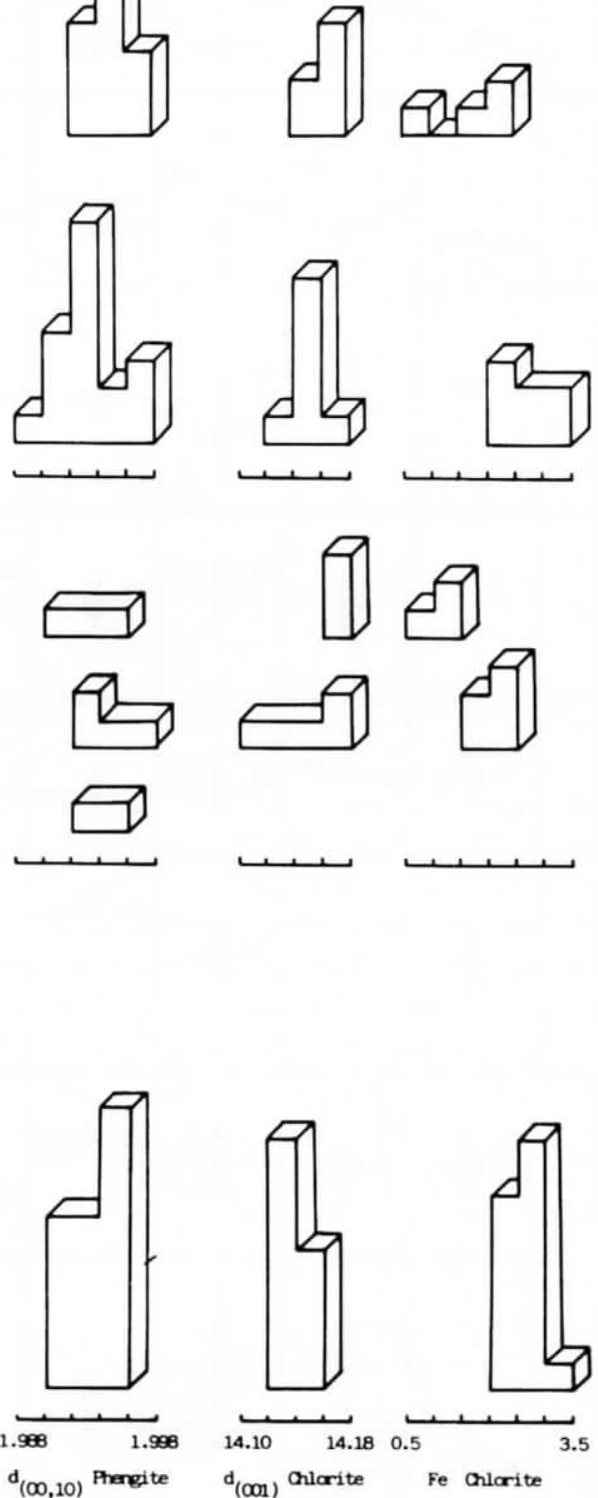

FIG. 2. Crystallochemical parameters of the phyllosilicates in the pebbles representing each of the various proposed source areas. Alpujárride Complex - a: Guadalfeo and Lújar Groups; b: Contraviesa Group. Nevado-Filábride Complex - I = Mulhacén Nappe. c: gneisses; d: schists; e: marbles. II = Veleta Nappe. f: mica-schists. 


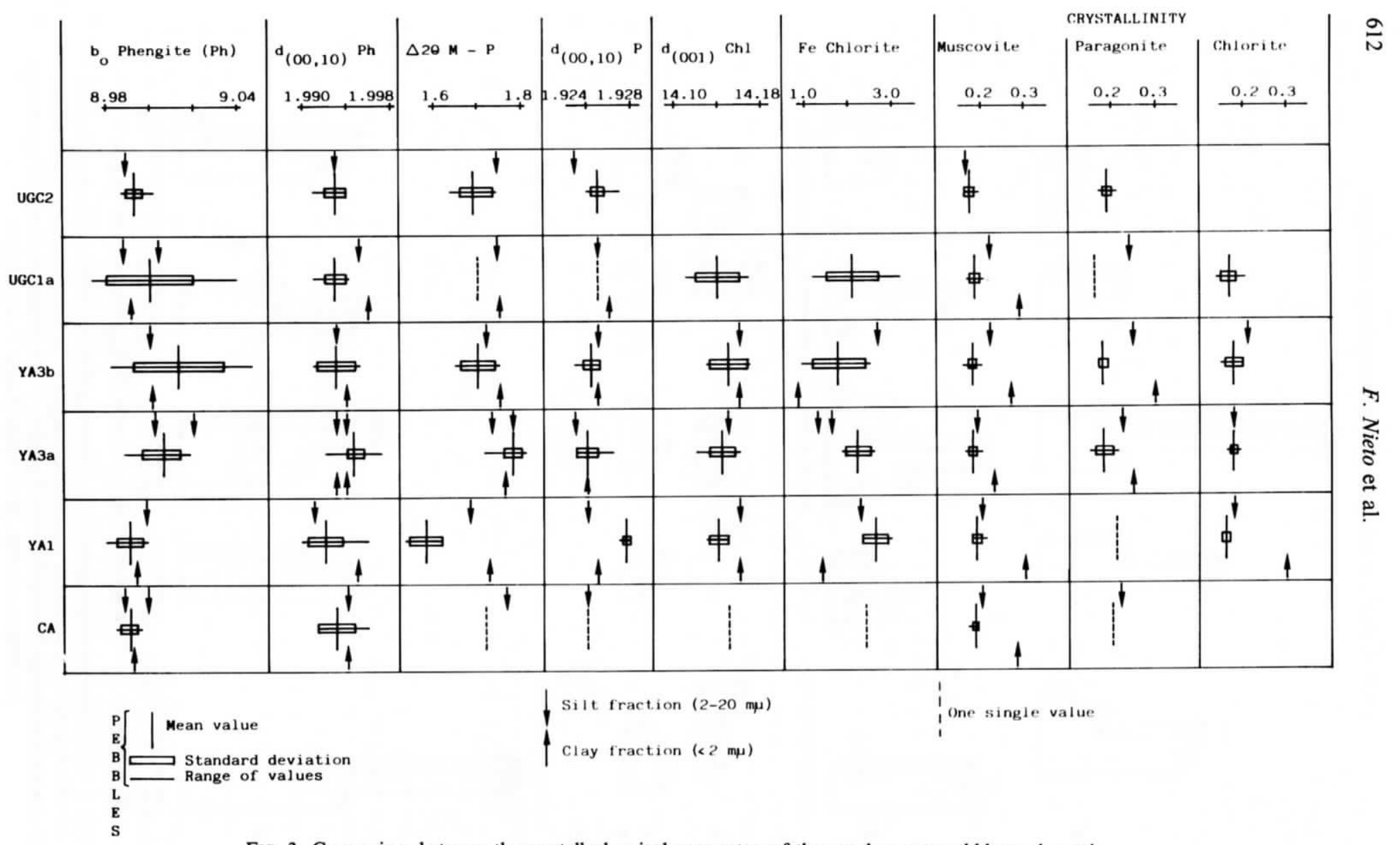

Fig. 3. Comparison between the crystallochemical parameters of the conglomerate pebbles and matrix. 
In this way the evolution of each crystallochemical parameter in relation to the physicalchemical alterations which took place in the materials during their journey from the source area to the sedimentary basin can be ascertained. The range of parameters for the pebbles in the conglomerates is the same as for the source rocks, while the values obtained for the phyllosilicates in the silt and clay fractions represent stages of initial and advanced alteration, respectively.

This hypothesis is confirmed by the crystallinity parameter for the three phyllosilicates in question, a parameter which is perfectly straightforward to interpret, particularly if it is measured precisely at the reflection which represents the crystalline perfection of the network alone (domain size and number of defects), and thus is free from the influence of other factors such as the effects of mixed-layer smectites, or the overlapping of reflections from other phases. In all the samples the silt-fraction crystallinity falls within the same range as, or is slightly poorer than, that of the pebbles, while the clay-fraction crystallinity is substantially poorer. This indicates that while the silt fraction has been only slightly altered by the sedimentation process, the clay fraction has deteriorated considerably.

The evolution of the crystallochemical parameters for the chlorite agrees well with the scheme reported in the literature (Liebling \& Scherp, 1976, 1980; Nieto et al., 1980; Nieto \& Rodríguez Gallego, 1981). The basal spacing has not been modified by any exogenous process. As can be seen in Fig. 3, the silt- and clay-fraction values are systematically the same, falling within the variation interval of the chlorite in the pebbles. Any small differences that may exist cannot be attributed to a loss in crystallinity but to the degree of precision of the measurements. Consequently, this parameter proves to be an excellent indicator of the source area for the materials, even when they are highly degraded.

The Fe content of the chlorite, on the other hand, is a very sensitive pointer to the degree and the nature of the alteration of the rocks. In the Alpujarran Corridor, where the conditions of the sedimentary environment were open and energetic, the process involved frequent changes of oxidant solutions which leached out the Fe content, as described by Nieto \& Rodríguez Gallego (1981). Compared to the pebbles, this loss is much greater in the clay fraction than it is in the silt. It is also noteworthy that there is a clear relationship between the decrease in $\mathrm{Fe}$ and the loss of crystallinity.

The parameters for the micas also show differing evolution patterns. While the $b_{0}$ has not been significantly affected by the sedimentary process, the basal spacings have been modified. The $b_{0}$ values for the micas in both the silt and clay fractions are more or less the same, and also fall within the variation limits observed for the pebbles, or else differ to such a slight extent (the third decimal place) as to be insignificant, taking into account the margin of experimental error permissible with clay and silt fractions. These values appear to have a similar significance to those of the $d(001)$ basal spacing of the chlorite. Consequently this parameter can also be used as an indicator to the source area for the sediments, especially the silts, at least when only relatively mild weathering processes have been involved.

On the other hand, the basal spacing of the muscovite and paragonite and the angular difference between the 00,10 reflections of both micas are very sensitive parameters to the sedimentary process. As can be seen in Fig. 3, significant variations occur between the values obtained for the pebbles and those for the silt and clay fractions. Furthermore, a clear relationship exists between the degree of alteration of the micas, revealed by their loss of crystallinity, and the extent of the modification of the basal spacings. Where the variation is great, for example with the paragonite in the YA-1 sample, there is a considerable broadening of the reflection, accompanied by a significant diminution in the proportion of 


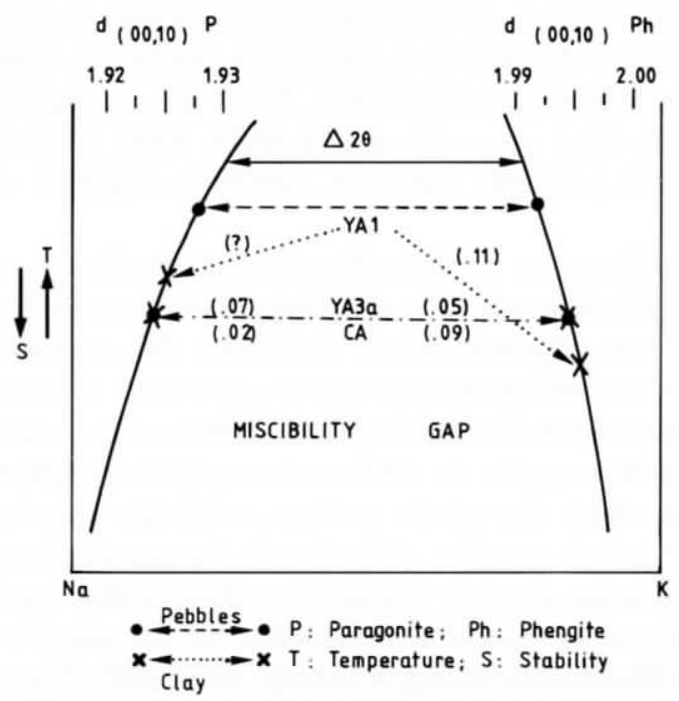

FIG. 4. Modification of the basal spacings of the micas and the muscovite-paragonite (angular difference $2 \theta$ ) due to effects during the sedimentary processes. CA: marine sample; YAl and YA3a: continental samples with high and low initial degrees of solid solution, respectively. The figures in brackets indicate the loss in crystallinity of the clay fraction compared to that of the pebbles. The $T$ and composition scales have been chosen arbitrarily. Scheme based on Fig. 4 of

Essene (1982) and Eugster et al. (1972).

mica affected, which may even render it difficult if not impossible to measure the crystallinity.

One further difference worth noting is that which exists between the materials deposited in a continental environment and those deposited in a marine environment. In the former there is a significant increase in the $\Delta 2 \theta$ muscovite-paragonite, as a result of the increase in the basal spacing of the muscovite and a decrease in that of the paragonite; the composition of each mica tends to polarize towards opposite extremes, each admitting a lesser quantity of the solid solution of the other (Fig. 4). The physical-chemical conditions of the exogenous environment tend to recreate more stable compositions at low temperatures. In fact, the samples most affected by such changes are those for which the original micas contained the highest quantities of solid solution, i.e. those formed at high temperature, such as in the YA-1 sample. On the other hand, those micas with greater angular increments, i.e. those formed at lower temperatures such as in the YA-3a sample, are much less affected by the process. Of the two micas, paragonite is affected much more intensely by the process described above than is muscovite.

However, the rocks from the Cádiar Sequence which were deposited in a marine environment were affected in a completely different manner, particularly as far as paragonite is concerned, as the basal spacing was not modified, and there was no significant loss of crystallinity. The chemical effect of alkaline-rich sea water on the paragonite structure must have been minimal compared to that of continental water, which acted upon the interlaminar cations of the micas. The composition of the micas in the continental environment tended towards the extremes of the solid-solution series, which are the only ones stable at low temperature. 
Thus, it can be seen that analysis of the basal spacing of muscovite and paragonite and their angular difference, and a comparison of these parameters within the various fractions may well afford important clues to the character of the sedimentary environment and the intensity of the alteration processes which occurred.

\section{ACKNOWLEDGMENTS}

This paper forms part of the Project 'Análisis sedimentológico, mineralógico y evolución tectosedimentaria de las Depresiones Béticas Orientales', subsidised by CAICYT and CSIC.

\section{REFERENCES}

Aldaya V., García DueÑas V. \& Navarro Vilá F. (1981) Los mantos Alpujárrides del tercio Central de las Cordilleras Béticas. Ensayo de correlaciòn tectònica de los Alpujárrides. Acta Geol. Hisp. 14, 154-166.

BrINDLey G.W. (1961) Chlorite minerals. Pp. 242-296 in: The X-ray Identification and Crystal Structures of Clay Minerals (G. Brown, editor). Mineralogical Society, London.

Cuevas F., Martin Penela A., Rodríguez Fernández J., Sanz de Galdeano C. \& Vera J.A. (1984) Première datation du Turolien à la base de la Formation de Guadix (Secteur Abla, Almeria, Espagne). Geobios 17, 355-361.

ESSENE E.J. (1982) Geologic thermometry and barometry. Pp. 153-196 in: Characterizaton of Metamorphism through Mineral Equilibria (J.M. Ferry, editor). Mineralogical Society of America.

Eugster H.P., Albee A.L., Bence J.B., Thompson J.R. \& Waldbaum D.R. (1972) The two phase region and excess mixing properties of paragonite-muscovite crystalline solutions. J. Pet. 13, 147-179.

Evans B.W. \& GuIDOTTI C.V. (1966) The sillimanite-potash feldspar isograd in Western Maine, U.S.A. Contr. Min. Pet. 12, 25-62.

LIEBLING R.S. \& SCHERP H.S. (1976) Chlorite and mica as indicators of depositional enviroment and provenance. Bull. Geol. Soc. Am. 87, 513-514.

LIEBLING R.S. \& SCHERP H.S. (1980) Chlorite and mica as indicators of provenance. Clays Clay Miner. 28, 230232.

López Aguayo F., Ortega Huertas M. \& Velilla N. (1986) Procesos de alteración supergénica en Sierra Almagrera: Mineralogia de las rocas encajantes. Bol. Soc. Esp. Mineralogia 9, 291-298.

Martín Ramos J.D. (1977) Las micas de las Cordilleras Béticas (Zonas Internas). Ph. thesis, Univ. Granada, Spain.

Martín Ramos J.D. \& Rodríguez Gallego M. (1976) Barometria y termometria geológica mediante parámetros cristalográficos de micas. Aplicación a la Cordillera Bética. Reun. Geodinámica de la Cordillera Bética y Mar de Alborán 115-124.

Nieto F. (1983) Las cloritas de las Cordilleras Béticas. Ph. thesis, Uni. Granada, Spain.

Nieto F., Ortega-Huertas M. \& Sebastián E. (1980) Cloritas en sedimentos postorogénicos de las Depresiones de Granada y Guadix-Baza. Estudio cristaloquimico. Estudios Geol. 36, 111-121.

Nieto F. \& Rodríguez Gallego M. (1981) Alteración experimental de cloritas. Acad. Ciencias Mat., FísicoQuim. y Nat. de Granada 1, 108-124.

Nieto F. \& Rodríguez Gallego M. (1983) Metodología para el estudio de la clorita en rocas metamórficas. Rendiconti Soc. Italiana di Miner. e Pet. 38, 1429-1436.

Ortega-Huertas M., Nieto F., Rodríguez Fernández J. \& López Garrido A.C. (1985) Mineralogía y estratigrafia de sedimentos neógenos del Corredor de la Alpujarra (Cordillera Bética, España). Bol. Soc. Esp. Mineralogia, 8, 307-318.

Puga E. (1971) Investigaciones petrologicas en Sierra Nevada. Ph. thesis. Univ. Granada, Spain.

Rodríguez Fernández J. (1982) El Mioceno del sector central de las Cordilleras Béticas $\mathrm{Ph}$. thesis, Univ. Granada, Spain.

Sanz de Galdeano C., Rodríguez Fernández J. \& López Garrido, A.C. (1985) A strike-slip fault Corridor within the Alpujarra Mountains (Betic Cordilleras, Spain). Geol. Rund. 74, 641-655. 
Sanz de Galdeano C., Rodríguez Fernández J. \& López Garrido A.C. (1986) Tectonosedimentary evolution of the Alpujarran Corridor (Belic Cordilleras, Spain). Giornale di Geologia, 48, 85-90.

Velilla N. (1983) Los granates del Complejo de Sierra Nevada (Cordillera Bética) Ph. thesis, Univ. Granada, Spain. 